\title{
The Global Context of Human Rights Violations: The Impact of the Alien Tort Claims Act
}

\author{
John Betton \\ University of Wisconsin-La Crosse, United States
}

\begin{abstract}
${ }^{2}$
Corporate responsibility for human rights violations has historically been approached as a domestic national issue in the United States. That is, despite international legislation governing human rights violations in an international context, courts have generally held that the activities of U.S. corporations outside the United States involving individuals who are not U.S. citizens does not fall within the jurisdiction of U.S. courts. This has been consistently affirmed at the Supreme Court level; and, indeed, the court has been zealous in seeking to avoid any reference at all to legislation like the European Human Rights Act in writing opinions.
\end{abstract}

This view of culpability for human rights violations has recently changed, both informally, with the emergence of global guidelines regarding human rights applying to corporations such as the Global Reporting Initiative, Amnesty International Guidelines and O.E.C.D. guidelines for Transnational Corporations and with the application of an $18^{\text {th }}$ century law, the Alien Tort Claims Act, that has been used to sue corporations for human rights violations outside the United States.

A suit was brought against Unocal, a California based oil corporation, for complicity in crimes committed against Burmese citizens under this Act. The 9th District Circuit Court of Appeals held in this case that Unocal had a case to answer for complicity in the rape and murder of Burmese citizens perpetrated by the ruling military junta. Recently, Unocal settled out of court in what is reported to be a sizeable financial settlement. Additional lawsuits have been brought against Ford Motor Corporation for its complicity in the holocaust by providing military vehicles to the German Army through their German subsidiary and I.B.M. for providing counting machinery for concentration camps during the Second World War. Cases involving other countries include the conduct of business with the South African apartheid government by several U.S. based corporations. These cases raise a new concept of corporate responsibility in a global setting as they depend upon an assumption of moral responsibility by corporations for violations of human rights committed by regimes with which they do business. This paper examines the implications of this changed context for corporate responsibility in the context of the emergence of the multiple voluntary guidelines that seek to hold corporations accountable for conduct outside their own countries.

\section{Keywords}

Copyright (C) 2008 Victoria University. This document has been published as part of the Journal of Business Systems, Governance and Ethics in both online and print formats. Educational and non-profit institutions are granted a nonexclusive licence to utilise this document in whole or in part for personal or classroom use without fee, provided that correct attribution and citation are made and this copyright statement is reproduced. Any other usage is prohibited without the express permission of the
ATCA, Human Rights, Corporate Governance, CSR

\section{Introduction}

Social expectations of corporate behaviour have produced increased attention to issues of corporate governance and to issues that generally fall within the rubric of corporate social responsibility. While it is clear that

2

An earlier, preliminary version of this paper was presented at the Second International Conference on Corporate Social Responsibility in Berlin, Germany 
over the past decade, there has been a rapid growth in the number of non-governmental organizations (NGOs) addressing social responsibility and in the number of voluntary guidelines concerned with corporate social responsibility, the evolution of this concept has been somewhat ambiguous in a global context.

At one level, national systems via constitutional, judicial or legislative mechanisms provide frameworks for defining corporate responsibility; these generally are domestic in scope. The rapid growth of multinational and transnational corporations facilitated in part over the past two decades by the formalization of international trade rules and financial architecture has resulted in a more global context for concerns about corporate social responsibility.

It is clear at the start of the twenty-first century that few businesses operate in ways that are unaffected by globalization. The operations of global corporations represent a particular challenge, both because the revenues of the largest global corporations far exceed the GNP of many nation states and because, for some corporations, it is increasingly unclear whether describing them as "national" entities has much meaning. Organizations like DaimlerChrysler or Royal Dutch Shell, for example, cannot be viewed as German, America, British or Dutch in any meaningful way. For these organizations, national legislation affects only the parts of their operations operating in particular local (national) contacts.

The impact of trade rules following the formation of the WTO has, for example, facilitated the operations of corporations globally, but has also resulted in constraints on their behaviour being largely defined in the national contexts in which they operate. For example, Swedish corporations which in Sweden are subject to fairly stringent environmental legislation may also operate in nation states where there are few, if any, such regulations and if such regulations exist, may be enforced to a limited extent, if at all. There is a dilemma, then, in that nation states may be able to regulate the activities of their corporate "citizens" in their domestic jurisdictions; however, such regulation cannot normally extend to a global context. This has resulted both in corporations seeking competitive advantages through production in poorly regulated or non-regulated environments and fierce opposition by corporations (particularly corporations based in the U.S.) to any such global regulation. As Roth (2005) comments, "Most multinational corporations automatically oppose calls for enforceable standards of corporate social responsibility. Under growing public scrutiny of their behaviour, many western companies have adopted voluntary codes of conduct. But for most, the notion of enforceable standards remains anathema."

The dilemmas and contradictions of corporate social responsibility are examined in the discussion that follows. The discussion briefly reviews the emergence of voluntary guidelines regarding corporate social responsibility with a particular focus on human rights. Next, the traditional antipathy of the U.S. to global legislation is considered in the context of global operations of transnational corporations. The key development with regard to corporate social responsibility, it is argued, is the emergence, despite substantial political and corporate opposition of cases involving the Alien Tort Claims Act, part of an $18^{\text {th }}$ century U.S. statute. This act (ATCA, also sometimes referred to as Alien Torts Statute), it is argued, represents an important advancement on voluntary guidelines as it sets precedent for international law. The act, via reference to the "law of nations" both extends judicial jurisdiction by U.S. courts to human rights violations committed by corporations in other countries and also suggests in the opinion in the recent Unocal case that corporations conducting business with government agencies or entities in other countries may be held to be complicit in violations of human rights committed by those entities. What is interesting is that the ATCA by reference to the law of nations appears to create precedents for reviews of human rights violations under international law. The history of the act and some examples of cases brought under this legislation are considered in this paper. Although many of these cases have been dismissed, it is clear from court holdings in Unocal and the albeit narrow upholding of the right to bring cases under this act in Sosa that what is emerging is a series of challenges to corporate actions with regard to human rights violations that will extend far beyond the U.S. 


\section{The Emerging Field of Corporate Social Responsibility Guidelines}

It is not the intent in this paper to review the voluminous literature on corporate social responsibility, but it is necessary to briefly review the emergence of voluntary guidelines, particularly as they affect the conduct of human rights. Robinson (1999) has summarized succinctly this field as comprising three basic areas, the protection of human rights, labour rights and the environment. In the context of this paper and the Alien Tort Claims Act, the focus is on human rights, although the act also has been utilized in tort cases involving the environment. Labour rights are obviously a key component of this analysis.

The recent emergence of guidelines and initiatives insofar as they relate to human rights largely originate in the conventions of the I.L.O founded after the first world war in 1919 and in the Universal Declaration of Human Rights of 1948. These documents provided key elements for a range of guidelines and initiatives institutionalized at a global level in the U.N. global compact and the subsequent emergence of the U.N. norms for transnational corporations. The U.N. human rights norms, for business adopted by the sub-commission on the protection and promotion rights in August 2003 identify key human rights responsibilities for companies including: “...ensuring equal opportunity and nondiscrimination, not violating or benefiting from the violation of the security of persons, protecting workers' rights, including freedom from forced labour and exploitation of children and a number of other rights within what are viewed as corporations' spheres of influence." (ESCR 2005) The U.N. norms are not an international treaty, however, and are not legally binding. Nevertheless, these "norms" have provided the basis for NGOs to interact with corporations regarding human rights violations (see, for example, cases documented in ESCR 2005 including the Global Justice Center and Candonga Consortium, Amnesty International and Union Carbide Corporation (Dow Chemicals), Oxfam and the Marinduque Mine, Amnesty International and Shell, and Human Rights Watch and Caterpillar).

Similarly, the OECD guidelines for multinational enterprises provide voluntary guidelines that are nonbinding but, like the U.N. norms, deal with discrimination, equal opportunity and child labour. Many of the human rights issues in these documents derive from the I.L.O. Tripartite Declaration based on I.L.O. conventions and recommendations but also considered the deliberations of the World Employment Conference and O.E.C.D. and U.N. documents. Issues of social responsibility have also been incorporated in the Global Reporting Initiative (see 2006 Draft Guidelines). The G.R.I. guidelines are concerned with sustainability but also consider the organization's impact on the social systems within which it operates. The G.R.I. social performance indicators identify key performance aspects surrounding labour practices, human rights and broader issues affecting consumers, community and other stakeholders. The guidelines note that the specific aspects under the category of labour practices and human rights performance are based on "international standards" such as the I.L.O. Conventions, the Universal Declaration of Human Rights, the I.L.O. Tripartite Declaration and the O.E.C.D. Guidelines.

Oldenziel (2005) has provided a valuable analysis of the value added by the U.N. norms to the O.E.C.D. guidelines, the U.N. global compact and the I.L.O. Tripartite Declaration. He points out that under international law, there are only two kinds of legally binding documents: treaties or customary international law and that the U.N. norms are not yet either but that "their language" is stronger and they have a more authoritative approach than existing standards. Where voluntary guidelines become problematic is they may easily become part of corporate public relations campaigns. Some companies, for example, signing on to the U.N. Human Rights Norms have been criticized by the human rights community for human rights violations. The dilemma is, of course, that voluntary guidelines do not generally have effective mechanisms or consequences for breaching those guidelines, or regulatory or judicial mechanisms that can enforce compliance. This is why the emergence and application of the Alien Tort Claims Act in the U.S.A. represents a significant aspect of accountability for human rights and other violations by corporations operating transnationally. What is particularly interesting is that the act has been applied recently in a political environment that has very much emphasized American 
"exceptionalism" and the premise in the U.S. that international law regulating extra-territorial human rights violations is superseded by domestic law.

Philippe Sands (2005) has noted, "with the election of George W. Bush in November 2000, a U.S. administration took office that was outspoken in its determination to challenge global rules" (p.xii). He adds that "there emerged a presumption against international rules; they no longer created opportunities but were seen as imposing significant constraints," (p.14) and "we are different...; the rules cannot apply to us." (p.15) Ignatieff (2005) has similarly commented, "At the same time (the U.S.A.) has also resisted complying with human rights standards at home or aligning its foreign policy with these standards abroad. Under some administrations, it has promoted human rights as if they were synonymous with American values, while under others, it has emphasized the superiority of American values over international standards." (p.1) As Ignatieff characterizes it, the United States signs on to international human rights and humanitarian law conventions and treaties and then "exempts itself from their provisions by explicit reservation, non-ratification or noncompliance." (p.3)

What makes it all the more interesting, therefore, is that an 18th century statute has proved to be a mechanism that, despite attacks by the U.S. business community and the current administration, has become a vehicle for establishing accountability for global human rights violations. It is also, it is argued, a more powerful mechanism than voluntary guidelines insofar as it constitutes international law (somewhat accidentally) and is more influential in what Hooker (2003) describes as a "rule based culture." As Hooker suggests, the U.S. is a low context culture with norms transmitted "explicitly" by legal requirements rather than by norms of behaviour.

What makes the Alien Tort Claims Act influential and the reason it has been attacked by the business community and the current administration is that it has the force of international law in that it permits the pursuit of civil actions for human rights and other violations in a global extra-territorial context. This statute is considered next, together with the applicability to corporations and human rights violations.

\section{Alien Tort Claims Act}

The Alien Tort Claims Act was adopted in 1789 by the first U.S. Congress as part of the original judiciary act and states that, "The district courts shall have jurisdiction of any civil action by an alien for a tort only, committed in violation of the law of nations or a treaty of the United States" (Title 28.IV.ch85s1350). What makes the act interesting and provided a mechanism for addressing global human rights violations is that it refers to "aliens," "violations of the law of nations" and "a treaty of the United States." This provides for cases to be brought by non U.S. citizens and also globalized the application of torts placing them in the context of the law of nations and also integrating them with international treaties such as the U.N. Convention on Torture which the U.S. was signatory to.

The law of nations has had a long and interesting history. Rather than constituting specific legislation, "from the time of the Peace of Westphalia of 1648 and the emergence of a still substantially intact system of nation states, the law of nations has been pretty much what contemporary nations have agreed to in writing" (Moynihan, 1990, p.9). During the colonization of the new world, the "law of nations" was widely used to justify territorial claims in the guise of "national law." Elizabeth I of England in the 16th century, for example, claims the "law of nations" meant that territorial claims should not, "hinder other persons from carrying on commerce in these regions...nor from navigating the vast ocean." (Cheyney 1905) This brief reference in the judiciary act clause (ATCA) thus positioned alien torts firmly within the evolving context of customary international law.

Beginning in 1979 in the landmark Filártiga v. Peña-Irata case (Filártiga v. Peña-Irata, 630 F.2d 876,877 and n.2 (2nd cir 1980), U.S. courts have recognized "that a limited number of crimes including genocide, crimes against humanity, war crimes, torture, "disappearances," extrajudicial executions, forced labor and prolonged arbitrary detention, violated the "law of nations" and that claims for such abuses can, therefore, be brought under the ATCA (HRW 2003). The Torture 
Victim Protection Act of 1991 (TVPA) approved the Filártiga decisions regarding the ATCA and extended rights to U.S. citizen plaintiffs to bring claims against individuals acting under "actual or apparent authority, or color of law, of any foreign nation." (HRW 2003) The Filártiga case was brought under the Alien Tort Claims Act and established that U.S. courts had jurisdiction over noncriminal abuses that occurred anywhere in the world, "so long as the alleged wrong would violate international law" (Slaughter and Bosco 2006, p.1). Issues arising from the rulings in Filártiga were examined by the U.S. Supreme Court in the case of Sosa v. Alvarez-Machain. The Supreme Court decision established that "victims of egregious international human rights violations have a right to sue perpetrators found within the United States for monetary compensation (Hoffman 2006). The implications of Sosa were far reaching for the business community in the context of human rights issues.

\section{Alien Tort Claims Act and Transnational Corporations}

Following the early cases that resurrected the Alien Tort Claims Act plaintiffs sought to establish vicarious liability for the conduct of corporations outside the United States. Cases brought against corporations outside the United States. Cases included Exxon Mobil's activities in Aceh, Indonesia alleging human rights violations by security forces employed by Exxon, the use of paramilitary death squads targeting trade union leaders at Coca-Cola's plant in Colombia; the alleged use of torture by managers employed Del Monte in Guatemala and numerous other cases involving corporations like Dyncorp, Shell, Chevron and Rio Tinto. Of particular prominence are suits brought by victims of apartheid in South Africa and holocaust victims in Germany against companies complicit in crimes by those governments.

The South African cases (for example, the suit brought by Khulumani v. Berelays et al.) utilized the conclusion reached by the South African Truth and Reconciliation Commission that "business was central to the economy that sustained the South African State during the apartheid years " (cited in brief by Cohen, Milstein, Harsfield and Toll). The summary of the complaint notes that "this complaint seeks to hold those businesses that aided and abetted the apartheid regime responsible for the wrongs they made possible." (cited in brief)

This suit and others brought against companies doing business during the apartheid period in South Africa were consistent with U.N. sanctions imposed against South Africa at that time. For example, in December 1968, the General Assembly of the U.N. condemned "the main trading partners of South Africa and the activities of those foreign financial and other interests, all of which, through their political, economic and military collaboration with the government of South Africa and contrary to the relevant General Assembly and Security Council resolutions, are encouraging the government to persist in its racial policies" (General Assembly resolution A/RES/2396 (XXIII), 2nd December 1968 cited in Cohen, Millsfield et al document). Earlier, Archbishop Desmond Tutu had recommended a sum of $\$ 270 \mathrm{~m}$ be paid to an estimated 20,000 victims giving evidence to the Truth and Reconciliation Commission and called on businesses to contribute to the reparations process (BBC document "Pay Apartheid Victims Now" at http://www.bbc.co.uk). The U.S. lawyers pursuing the apartheid suit brought under the Alien Tort Claims Act sought $\$ 20$ billion in reparations from companies including NatWest, Barclays and Standard Chartered Banks (Robins 2004a). The lawyer representing the plaintiff, Ed Fagan, had personally headed efforts to secure multibillion out-of-court settlements from Swiss banks and German corporations, including subsidiaries of Ford and IBM. (Innocenti 2003) Interestingly, the South African Government of Thabo Mbeki was a partner in the request by companies to dismiss the suit. Penuell Maduna, Minister of Justice and Constitutional Development, stated, "The government accepts that corporate South Africa is already making a meaningful contribution to the broad national goals and rehabilitating the lives of those affected by apartheid." (Innocenti 2003) Thabo Mbeki, President, also commented, "We consider it completely unacceptable that matters that are central to the future of our country should be adjudicated in foreign courts which bear no responsibility for the well-being of our country." (Innocenti 2003) 
Like the South African example, ATCA cases have been contentious and have often prompted the intervention of governments. This was the case with the cases brought on behalf of holocaust victims, some of which were also initiated by Ed Fagan. Also involved was Stuart Eizenstat, deputy secretary of the treasury in the Clinton administration was also involved in intervening in cases brought against Swiss banks. (Robins 2004b)

The agreements involving the U.S. government in these cases since 1998 when the first settlement took place, reached by 2001 a figure of $\$ 8-11$ billion. (Bazyler 2004)

Other cases brought against corporations that have attracted a lot of attention include: WIWA v. Royal Dutch Petroleum, cases brought against Exxon Mobil in Aceh which prompted intervention by the Attorney General of the U.S. and the Bush Administration (discussed in the next section), Coca-Cola and paramilitary death squads, Del Monte and numerous other cases. In general, many of these cases have failed either because of jurisdictional problems, an inability to demonstrate influence over the defendant by the corporations involved or absence of "knowing complicity." The case that has attracted the most recent attention has been Unocal. The case has prompted both antagonism by the business community and enthusiasm by the human rights community.

The U.S. company, Unocal, was sued for complicity in forced labour, rape and murder by the Burmese government. Two landmark cases Doe v. Unocal and Roe v. Unocal were brought on behalf of Burmese villagers. In April 2005, Unocal agreed to compensate Burmese villagers. Chambers (2005) has commented that the final settlement "brought widespread cheer to those who hope to make transnational corporations accountable for their perpetration of and complicity in human rights abuses." (p.14) As Chambers (2005) points out, the Unocal litigation had proceeded "further than any other case brought under the ATCA." (p.14) Another company implicated in Burma, Total, the French oil corporation, also settled in 2005 for 5.2 million Euros. What was interesting about the Unocal case was the holding by the 9th District Circuit Court of Appeals that reversed the lower court's decision in finding that there were genuine issues of material fact that concerning Unocal's complicity in rape and murder by the Burmese government. (Doe v. Unocal Corp., 395f3d 932 (9th cir. 2002). This case and the Exxon Mobil case in Aceh, Indonesia prompted considerable response by the business community.

\section{Alien Tort Claims Act and the Business Community}

The court decision in the apartheid cases discussed earlier by Judge John Sprizzo emphasized considerable caution in "permitting suits here based upon a corporation's doing business in counties with less than stellar human rights records." (Birchall 2005) and seemed to signal that the Alien Tort Claims Act did not represent a significant issue for U.S. companies doing business abroad. The Unocal decision, however, suggested that companies were, indeed, vulnerable to litigation brought under the act. One of the lawyers in the case was cited as stating, "You companies are capable of knowing right from wrong and what we are telling you is that if you put yourselves on the side of wrong, then there is some room under this statute for you to get sued." (Birchall 2005)

Similarly, Taylor and Ruge (2005) have commented that companies "must be prepared to answer critical questions about whether their operations are in accordance with international law." (p.1) A more emotional response was provided by Niles (2002) who asked, "What might happen if U.S. courts increasingly assert jurisdiction over such cases?" (p.1) and "Unless Americans are prepared to accept these risks, as well as the accompanying danger that the U.S. judicial system will become the world's civil court of first resort, the U.S. government needs to act now to curb misuse of the Alien Tort Claims Act.” (p.1) Bauer (2006) cites Phil Rudolph of the Ethical Leadership Group and former international general counsel for McDonald's as stating that, "Frankly, the greatest risk to companies facing ATCA is reputational" and "in the court of public opinion, Unocal suffered mightily." (p.13)

Shrage (2003) suggests that the Alien Tort Claims Act is "just the beginning" and that now "any meaningful defense of (ATCA) Claims will require a company to show that it has made a good faith effort to closely examine local practices and ensure that they meet international human rights 
standards." (p.17) As he says, "claiming ignorance of relationships with business partners "will not be credible." (p.17) A similar warning came in Britain from Herman (2006) who described "a growing threat of being sued in the U.S. over (their) dealings with foreign governments accused of human rights violations" (p.1) and cites Roe Lindsay, a partner at Clifford Chance as claiming the ATCA is having a detrimental impact on foreign investment by U.K. companies and John Trenor, a partner in a British law firm, as suggesting that "litigation in U.S. courts under the Alien Tort Claims Act seeking to hold companies liable for alleged international law violations at the hands of government or others can present a serious threat to U.K. and other companies doing business round the world." (p.2) Collingsworth (2004) referring to corporate social responsibility as "a charade" comments that many "leading" business organizations (including some who were signatory to the U.N. global compact) filed a brief in Sosa v. Alvarez-Machain urging the Supreme Court to nullify the ATCA. He notes that their brief asserts, "(ATCA) lawsuits harm the economy by putting companies with a U.S. presence at a unique and unfair competitive disadvantage (p.1). Collingsworth tellingly makes the point that codes of conduct by these major corporations and their claimed support for various international initiatives like the global compact constitute "simply public relations misrepresentations" (p.2) when viewed in the light of their opposition to the ATCA.

Amicus briefs filed by the U.S. government in conjunction with briefs by these corporations in Doe v. Unocal and Roe v. Unocal made similar claims. Not only did the U.S. government intervene in the Unocal case, but it also intervened in the suit against Exxon Mobil Corporation for alleged complicity in human rights violations in Indonesia. The U.S. government's position not only raised arguments concerning business interests but argued that the Indonesian government would view judicial scrutiny of the company's conduct as a referendum on the human rights record of the Indonesian armed forces which would dissuade it from cooperating with the U.S. on counter terrorism." (Human Rights Watch, 2002) The U.S. Chamber of Commerce has referred to the ATCA as "litigation run amok" in an article that claimed, "Your company could be sued — by foreigners in U.S. courts - if you simply did business in, paid taxes in and complied with the laws of a foreign country in which those foreigners alleged an atrocity occurred." (Bruno 2003, p.6)

What seems clear is that the proliferation of suits brought under the Alien Tort Claims Act has raised issues of corporate responsibility for human rights violations that have redefined these global responsibilities and perhaps represented corporate responsibility in a way that has shifted the debate from voluntary codes of conduct to emerging international law. This shift in the debate is evaluated in the concluding section of this paper.

\section{Conclusions - The Shifting Debate on Corporate Social Responsibility}

The issue of corporate social responsibility which continues to evolve through avenues involving voluntary norms, standards and initiatives as well as through mechanisms that have implications for customary international law has remained somewhat ambiguous. Critics have charged that it represents little more than astute corporate public relations. Supporters of the concept point to cases like the Gap Corporation where there have been significant changes such as the acceptance of independent auditing of labour practices.

From a corporate perspective, however, the key issue seems to be one of regulation. While many corporations were willing to be associated with the U.N. global compact, there has been considerably more antagonism to the Norms for Transnational Corporations which are viewed as more of a threat as they incorporate supply chain responsibility that, as Oldenziel (2005) points out, goes far beyond the weak phrasing of the OECD guidelines. In addition, there are external and internal monitoring processes.

However, the U.N. norms are, "not a treaty which states ratify and lead to binding legal obligations and certainly not international law." (Oldenziel 2005, p.19) Nevertheless, the norms may in the future evolve 
into having some legal effect. Indeed some applications of the norms have already been made (for example, to the Alcan Corporation in Brazil, the Union Carbide Corporation, and the Placer Dome in the Philippines (ESCR 2005). Even the implication of possible international legal obligations has prompted considerable criticism by organizations like the International Chamber of Commerce. None of these voluntary norms or even norms which have the possibility of becoming established via U.N. tribunals as possible precedents has attracted the degree of opposition by transnational corporations that recent cases brought under the Alien Tort Claims Act has attracted.

What is interesting about the Alien Tort Claims Act is by reference to the "Law of Nations" and by U.S. Supreme Court Decisions regarding issues like torture, it is being embedded in and has the force of international law premised on the idea of complicity. The cases brought against transnational corporations so far have focused on "the obligation of corporate actors not to assist others in the commission of human rights abuses." (Manzella p.1) As Manzella (2006) points out, "Anyone that knowingly provides practical assistance, encouragement or moral support that has a substantial effect on the perpetration of a human rights abuse violates international law" (p.1), a principle applied at the Nuremburg Tribunals and also at International Criminal Tribunals in Yugoslavia and Rwanda (Manzella 2005). This principle has the same basis as decisions regarding ATCA cases.

The recent Earth Rights Report (Manzella 2005) identifies the issue of direct complicity that emerged with the Nuremburg Tribunals' findings that corporations were liable for expropriation and labour violations during the Nazi regime (e.g. I.G. Farber and Krupp). These standards of complicity are noted in the U.N. norms, but have also been applied directly under prosecutions brought under the ATCA. Under U.S. law, corporations are "persons" and thus can be treated as complicit in the same way as individuals. The recent case of Presbyterian Church of Sudan v. Talisman Energy, Inc. (374F.Supp. 2nd 231, 337-41) established that "there is no disagreement that the notion of aiding and abetting liability in international law is a core principle that forms the foundations of customary international legal norms." (Manzella 2005, p. 11)

The U.S. Supreme Court has both adopted this principle of international law and contributed to its development through its recent decisions in cases brought under the ATCA. The Sosa case established that federal courts could hear such cases despite a campaign of opposition from the business community. As Apple (2004) points out, the Sosa case rejected the business lobby position that corporations should not be held liable under the ATCA and the Bush Administration position that the ATCA should not be applied by the courts (Apple 2004). The recent Unocal case reiterated the question of whether corporations can be complicit in acts violating human rights committed by business partners. The 9th District Court of Appeals held that they had such accountability, and as Apple (2004) suggests, "By addressing the question of corporate complicity in human rights abuses, the courts have taken on one of globalization's biggest problems: Multinational corporations have achieved unprecedented international power without corresponding global accountability." (Apple 2004, p.19) Despite many cases brought under ATCA being dismissed largely because they were not achievable under the law of nations or on procedural grounds, a number of cases have been settled out of court because of the likelihood of their being successful, including Unocal.

Given that the ATCA is the only U.S. legislation with a specific civil (tort) statute that permits foreign claimants "to seek civil redress from companies for breaches of international criminal and humanitarian law" (FAFO 2006) these decisions are critical to the development of accountability internationally for violations of human rights by corporations.

As Ellis (2005) has stated, "Corporations are looking more closely at the issue of corporate responsibility. They are beginning to see that business and human rights are not, as conventional wisdom has suggested, distinct and separate." (p.5) Baker (2006) cites the comment by John Ruggie, Special Representative on Human Rights and Transnational Corporations, that the most explicit definition of complicity (in human rights abuses) was that provided under the Unocal case. The criteria for complicity established in this were:

1. giving practical assistance to the actual perpetrator of a crime, 
2. the requirement that such assistance had a substantial effect on the commission of the criminal act; and

3. the company knew or should have known that its acts would result in a possible crime even if it did not intend for the crime to take place.

This obviously has been of great concern to some businesses with organizations like the International Chamber of Commerce calling the jurisdiction under ATCA "unacceptable" (Bruno 2003). However, as Ruggie (2005) has pointed out, "the raw statistics favour the companies." As at the end of 2005, twenty-one cases have been dismissed under ATCA, sixteen are ongoing, and only three have been settled. He suggests that ATCA's power has been "mainly existential" but that "the mere fact of providing a remedy for certain human rights abuses companies may have committed abroad has made a difference to corporate human rights practices." (p.3)

Collingsworth (2002) considers that as litigation of international law issues under ATCA becomes more common, links between violators and defendants will become "an extremely valuable part of the enforcement process." (p.10) Howen (2005) has made the point that, "We need global rules because most large corporations have overgrown the ability of many individual states to regulate them effectively." (p.5) Slaughter's (2001) conclusions are that, "Beyond their significance for individual litigants, these suits are also part of an important trend in international law. Increasingly, national courts are becoming involved in global issues. At the same time, states are creating new international tribunals and granting new power to established international courts. The result is an increasingly complex transnational justice system, in which international, national and regional courts interact and overlap. Management of this complex system to defend fundamental values will be one of the great challenges ahead." (p.4)

The recent decisions under ATCA prompt the question of whether the way forward in the globalization of business and human rights lies in the role of social norms or by legal compliance. Howen (2005) argues that there is a need for binding human rights rules related to corporate accountability but that "what divides some companies from many human rights advocates is whether human rights should be a matter of obligation or voluntarianism." (p.9) Certainly, there has been enormous opposition by some corporations to the development of legislation that acknowledges the liability that corporations have for complicity in human rights violations committed by governments or other actors with whom they choose to do business. There also has been considerable debate as to whether progress in this area will be effective via voluntary processes or by forcible legal compliance resulting from litigation. ATCA has been criticized by some constituencies. On the other hand, as Richard Hermer, a barrister at Doughty Street Chambers in London has commented, "It is entirely right and appropriate that those companies that involve themselves in disreputable practices are held to account, if necessary, through the courts. Adopting socially responsible policies should be a priority for business, not least because it is in their own self interest." (Herman 2006, p.2)

\section{References}

Amnesty International, 'Human Rights Principles for Companies,' available at http://web.amnesty.org/library

Baker, M 2006, 'Mapping out the way ahead for business and human rights' Business Respect no. 90, $12^{\text {th }}$ March. Archived at Mallenbaker.net

Baue, B 2006, 'Win or Lose in Court', Business Ethics, Summer, pp. 12-13.

Bazyler, M 2004, 'Suing Hitler's Willing Business Partners: American Justice and Holocaust Morality,' Jewish Political Studies Review, Fall, no. 16, pp. 3-4.

Birchall,J 2005 'The limits of Human Rights Law', Financial Times, Jan. 20, p.6.

Bruno,K 2003, 'De-globalizing Justice' Multinational Monitor, 24, no. 3, pp. 1-6.

Chambers, R 2005, 'The UNOCAL Settlement: Implications for developing law on corporate complicity in Human Rights Abuses', Human Rights Brief, 13 no. 1, pp..14-36. 
Cheyney, E 1905, 'International Law under Queen Elizabeth', English Historical Review, xx no 80, pp. 659-72, cited in Law of Nations and the New World, 1993, ed. Green, L C and Dickason O P Edmonton, University of Alberta Press.

Cohen, M, Hausfield and Toll, P.L.L.C. Case Watch document on apartheid litigation at http://www.cmht.com/casewatch/cases/apartheid-plaintiffs.html

Collingsworth, T 2002, 'The Key Human Rights Challenge: Developing Enforcement Mechanisms', Harvard Human Rights Journal, Vol. 15, Spring, pp 183-204.

Collingsworth, T 2004, 'U.S. Companies Ask Supreme Court to Nullify ATCA', News and Press at http://www.laborrights.org

Ellis, M 2005, 'Business Befriends Human Rights', European Lawyer, April 2005, p5.

E.S.C.R. (International Network for Economic, Social and Cultural Rights), 'U.N. Human Rights Norms for Business', available at http://www.escr-net.org

FAFO (2006), 'Assessing the Liability of Business Entities for Grave Violations of International Law', available at http://www.fafo.no/liabilities/

G.R.I.and Sustainability Reporting Guidelines available at http://www.globalreporting.org. See also draft G-3 Guidelines.

Herman, M 2006, 'British P.L.C.'s risk Human Rights Litigation in U.S., Lawyers Warn', TimesOnline, June 12.

Hoffman, P 2006, 'Courting Justice' Amnesty Magazine, p.1.

Hooker, J 2003, Working Across Cultures, Stanford, Stanford University Press.

Howen, N 2005, 'Business, Human Rights and Accountability', Speech at Business and Human Rights Conference, ICJ Copenhagen, 21 st September.

Human Rights Watch 2002, 'U.S./Indonesia: Bush Backtracks on Corporate Responsibility', Aug. 7, http://www.hrw.org

Human Rights Watch 2003, 'Background on the Alien Tort Claims Act', available at http://www.hrw.org

Ignatieff, M 2005, American Exceptionalism and Human Rights, Princeton,Princeton University Press. Innocenti, N 2003, 'Victims of Apartheid in South Africa dismiss U.S. Lawyer', Financial Times 11/6/03 p3.

Moynihan, D 1990, On the Law of Nations, Harvard, Harvard University Press.

'Norms on the Responsibilities of Transnational Corporation and Other Business Enterprises with Regard to Human Rights', UNDOC e/cn. 4/Sub 2/2003/12/Rev 2, (2003).

O.E.C.D. Guidelines available at http://www.oecd.org/EN/document

Oldenziel, J 2005, "The Added Value of the U.N. Norms: Report by SOMO Centre," April 2005

Robins, J 2004a, 'Apartheid Taunts Business' Financial Times, 9/13/04, p16.

Robins, J 2004b, 'Payback', The Lawyer, 8/23/04 archived at www.lawyer.com

Robinson, M 1999, 'Giving a Human Face to the Global Market' paper presented at WIN Conference $10^{\text {th }}$ June Interlaken, Switzerland.

Robinson, M 2003, 'Shaping Globalization,'The Role of Human Rights', Fifth annual Grotius Lecture. American Society of International Law 9th Annual Meetin, Washington, D.C., April . Archived at www.eginsinitiative.org

Roth, K 2005, 'Rules on Corporate Ethics Would Help, Not Hinder Multinationals', Financial Times, June 21 archived at www.hrw.org

Ruggie, J 2005, Business and Human Rights Seminar, London, Dec. 8th, 2005.

Sands, P 2005, Lawless World, New York, Penguin.

Shrage, E 2003, 'A changed World' Harvard Business Review, August, pp.16-18.

Slaughter, A M Undated, 'Crimes of War', downloaded from http://www.globalpolicy.org

Taylor, M and Roage, C 2005, "The Arm of the Law Gets Longer," FAFO document available at www.fafo.nl

"Tripartite Declaration of Principles Concerning Multinational Enterprises and Social Policy," available at http://wwwl.umn.edu/humanrts/links/tripartite.html 


\section{About the Author}

John Betton earned a Ph.D. from the University of South Carolina and is professor of Comparative Management at the University of Wisconsin-La Crosse, where he teaches business and human rights. 
